Institute of Microbiology and Virology, National Academy of Sciences of Ukraine, Kyiv

\title{
THE EFFECT OF P-NITROCHLOROBENZENE ON HOMEOSTASIS QUANTITATIVE PARAMETERS OF KARST CAVE CLAYS AND ECUADOR SOILS MICROBIAL COMMUNITIES
}

\begin{abstract}
In this paper it was given the effect of p-nitrochlorobenzene (NCB) on the homeostasis quantitative parameters of cave clays microbial communities from Westem Ukraine and Abkhazia (Mushkarova Yama, Kuybushevskaya) and soils of Ecuador tropical ecosystems. For these microbial communities were determined maximum permissible concentrations and types of responses on xenobiotic. Microbial communities of Mushkarova Yama cave clays and rainforest soils of Ecuador were characterized by the first type of response. Microbial communities of Kuybushevskaya clays and mountain jungles of Ecuador were characterized by the second type of response. Maximum permissible concentration of NCB for Mushkarova Yama was $200 \mathrm{mg} /$, for the other studied microbial communities $-300 \mathrm{mg} /$. It was shown, that microbial communities were not only highly resistant to NCB but also interacted with it by destroying this xenobiotic and decreasing its concentration in 4 times.
\end{abstract}

Ke y w ords: p-nitrochlorobenzene (NCB), karst caves, Ecuador tropical esosystems, microbial communities.

One of the main sources of pollution is waste waters from organic synthesis enterprises. There is special danger to the biosphere from xenobiotics included both nitro, chlorine and aromatic ring. $P$-nitrochlorobenzene (NCB) is one of such compounds. Its toxicity is determined by the aromatic ring and attached chlorine and nitro-group in the para-position. Bactericidal concentration for most soil and aquatic chemoorganotrophic microorganisms is $10 \mathrm{mg} / 1$ [1]. However, in several papers $[2,3,4]$ has been shown the ability of microbial communities of different ecosystems to function not only in the presence of bactericidal concentrations of extreme factors, but even in the higher concentrations. The aim of our work was to investigate the quantitative parameters of microbial communities homeostasis in the presence of toxic xenobiotic - NCB. When we talk about homeostasis in this context, we mean the ability of microbial communities to maintain vital functions influenced by extreme factors.

Materials and methods. Our aim was to study the microorganisms homeostasis in the presence of $\mathrm{NCB}$ (alien xenobiotic for the biosphere). That is why as objects of study we choose microbial communities of ecosystems differed significantly in physical and chemical factors:

- Mushkarova Yama cave clays ecosystems (Western Ukraine) and Kuybushevskaya (Western Caucasus, Abkhazia) with constant humidity, temperature, organic compounds concentration and absence of lighting;

- mountain jungle (the Andes mountain range, of Papallacta, $4020 \mathrm{~m}$ altitude) and the rainforest of Ecuador soils (of Puyo, $950 \mathrm{~m}$ altitude), opened ecosystems with dramatically changing climate, temperature and UV radiation.

Museum culture Escherichia coli and Clostridium lituseburense were selected as reference strains.

Microbial communities quantitative parameters of resistance (CFU, colony morphotypes number and diameter) were determined in liquid and agar media with NCB. As agar media Nutrient Agar (NA HiMedia Ltd.) and oligotrophic agar (OA) were used. As liquid - Nutrient Broth (NB) and oligotrophic broth. In order to get concentration range $50-300 \mathrm{mg} / \mathrm{l} \mathrm{NCB}$ aliquots of $\mathrm{NCB}$ alcohol solution were added in molten and cooled to $45-50^{\circ} \mathrm{C}$ agar medium. Petri dishes with $\mathrm{NCB}$ agar medium were kept in a desiccator with silicagel for removal of condensation moisture and sterility verification. Then the plates were inoculated with microbial suspensions of samples tenfold dilutions. The agar medium without NCB was used as a sterility 
control. Inoculated plates were exposed during 7 days in closed desiccators with a sterile silicagel. The number of $\mathrm{CFU}$, colony morphotypes and their diameter were the controlled criteria of microbial communities resistance to NCB.

Strains resistant to $N C B$ were determined in a liquid medium (NB, oligotrophic broth) in a concentration gradient of the xenobiotic (50-300 mg/l). Controlled parameter was the biomass growth, which was determined photocolorimetricaly by optical density of the liquid culture on KFK-2MP $(\lambda=540 \mathrm{~nm})$. Inoculated medium without xenobiotic was used as a growth control.

Determination of the ability to transform xenobiotic by microbial community and reference strains. Ecuador mountain jungle soil sample $(2 \mathrm{~g})$ was cultured in Nutrient Broth $(50 \mathrm{ml})$ in sealed bottles $(120 \mathrm{ml}$ ) in the presence of xenobiotic (concentration $100 \mathrm{mg} / \mathrm{l}$ ). Daily museum culture of E.coli and C.lituseburense were cultured in NB during 10 hours. During the experiment we monitored $\mathrm{pH}$, Eh, optical density, the concentration of xenobiotic and gas phase composition. The optical density was determined on photocolorimeter KFK-2MP $(\lambda=540 \mathrm{~nm}$, optical path $0.5 \mathrm{~cm})$. Indexes of $\mathrm{pH}$ and Eh were determined using a "pH meter pH-Milivoltmeter MA-150" potentiometer. For Eh measuring we used two electrods: measuring EVP-1 and chlorosilver comparison electrode EVL-1M3. For $\mathrm{pH}$ measuring - combine electrode ESK-10603/4.

Concentration of $\mathrm{NCB}$ and chloroaniline (ClA) in the liquid culture was determined by UV absorbance spectrum by using Specord-UV-vis $(\lambda=200-350 \mathrm{~nm})^{1}$. Absorption maximum of NCB is $215 \mathrm{~nm}, \mathrm{ClA}-265 \mathrm{~nm}$. In order to detect xenobiotic concentration NCB was extracted by hexane (1:10) from liquid culture supernatant.

Results and discussion. Samples of Mushkarova Yama and Kuybushevskaya (sampling depth $1 \mathrm{~km})$ caves clays and Ecuador natural tropical ecosystems soils $(4020 \mathrm{~m}$ height selection and $950 \mathrm{~m}$ ) were selected in polution-free areas without anthropogenic and technogenic influence on microbial communities. We determined maximum permissible concentrations of NCB for these ecosystems microbial communities (Fig. 1,2).

A

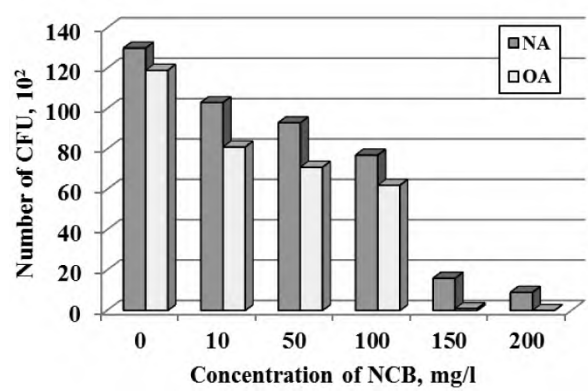

B

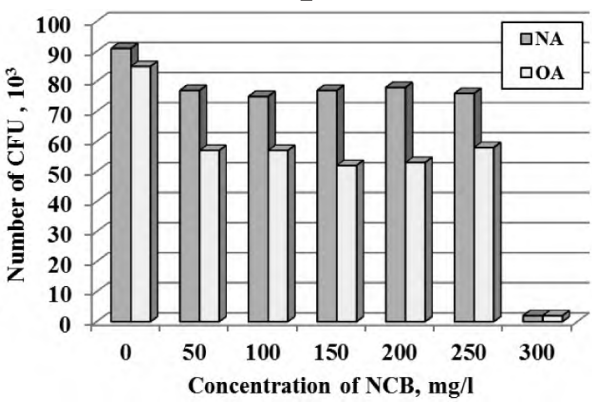

Fig. 1. NCB effect of the CFU number A. Mushkarova Yama; B. Kuybushevskaya

Note: To quantify parameters of resistance of caves microbial communities we used copiocarbotrophic medium (Nutrient Agar - NA with carbon concentration is $850 \mathrm{mg} /$ ) and oligotrophic medium (oligotrophic agar - OA with carbon concentration $85 \mathrm{mg} / 1$ ) due to the ability of cave microorganisms to grow in a wide range of organic compounds concentrations.

Maximum permissible concentrations of NCB for microbial communities of Mushkarova Yama and Kuybushevskaya clays were 200 and $300 \mathrm{mg} / 1$, respectively. In both cases, the number of surviving microorganisms was greater on the medium with high organic compounds concentrations (NA) comparing with the medium with a low organic compounds concentration oligotrophic agar $(\mathrm{OA})$.

The maximum permissible concentration of $\mathrm{NCB}$ for soil microbial communities of Ecuador mountain jungle and rainforest was $300 \mathrm{mg} / \mathrm{l}$ (Fig. 2). It should be noted that in all cases the number of CFU and morphotypes, and the diameter of the colonies decreased while

1 Absorption in the UV region is determined by the presence of unsaturated bonds in the aromatic ring. 
NCB concentration increased. Colony diameter in the concentrations of 100-300 mg NCB/1 was reduced in 6-7 times (from 4.5-7 $\mathrm{mm}$ to $0.5-2 \mathrm{~mm}$ ). Morphotypes number decreased from 4-5 to $1-2$ in all studied microbial communities.
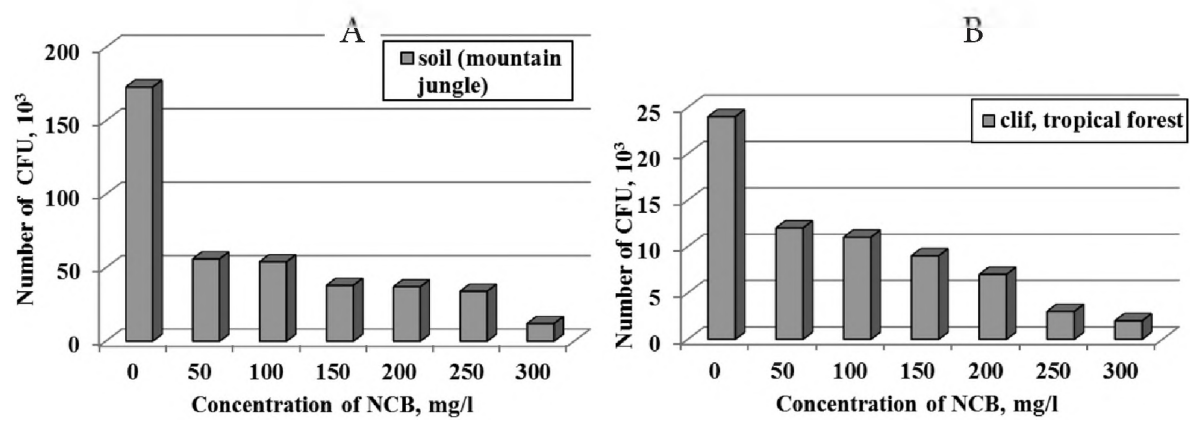

\section{Fig. 2. NCB effect of the CFU number, Ecuador rainforest and mountain jungle soil samples}

Note: To quantify parameters of resistance of tropical microbial communities we used copiocarbotrophic medium (Nutrient Agar - NA, the carbon concentration of $850 \mathrm{mg} / \mathrm{l}$ )

Previously we obtained data about the microorganisms resistance in terrestrial ecosystems (Antarctic cliffs, Negev desert soil, black soil Askania Nova, the soil of the Dead Sea, etc.) to extreme factors. It has been shown that there are two types of responses on the effect of extreme factors $[2,3]$. The first type of response, also called «correlative», represents inhibition of growth in increasing studied concentration range of xenobiotic. The second type of response represents absense of growth inhibition in the studied xenobiotic concentration range.

Similar types of responses have been shown in studied microbial communities in the NCB concentration gradient. Thus, the correlative response (the first type of response) was characterized for Mushkarova Yama and Ecuador rainforest soil microbial communities. The second type of response was observed for Kuybushevskaya karst cave and Ecuador mountain jungle microbial communities.

Studied microbial communities were not only highly resistant to NCB, but also able to transform it. There are three known ways of nitroclorinearomatic compounds transformation: nitro group reduction, dehalogenation and aromatic ring reduction [1].

Previously it was shown the non-specific p-nitrochlorobenzene reduction on the example of facultative and obligate anaerobic microorganisms museum cultures [5]. Microorganisms can degrade xenobiotic by two ways: reduction to $p$-chloroaniline ( $\mathrm{p}-\mathrm{ClA})$; reduction of the aromatic ring with subsequent cleavage of the cyclic compound.

We investigated the possibility of NCB transforming by Ecuador mountain jungle soil microbial community (Fig. 3).

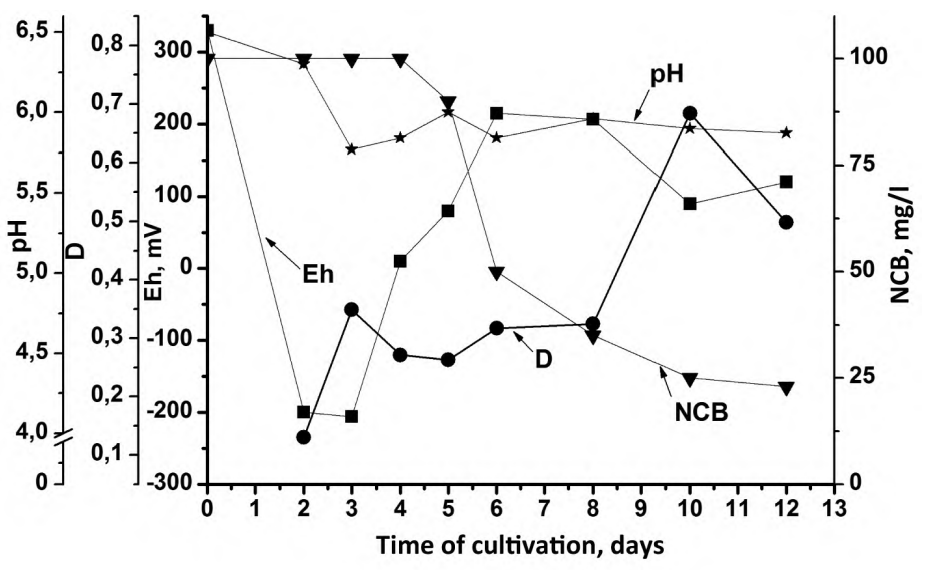

Fig. 3. NCB transformation by Ecuador mountain jungle soil microbial community 
The initial concentration of xenobiotic was $100 \mathrm{mg} / \mathrm{l}$. It decreased in 4 times during cultivation ( 12 days). The appearance of ClA was not observed. Thus, for Ecuador mountain jungle soil microbial community was shown the second way of NCB destruction - reduction of the aromatic ring with subsequent cleavage of the cyclic compound.

On an example of museum cultures we showed dynamics of NCB reduction (Fig. 3 and Fig.4). Thus, the growing culture of E.coli reduced NCB (initial concentration was $10 \mathrm{mg} / 1$ ) to $\mathrm{ClA}$ in 1.5 hours (Fig.4). A museum culture C.lituseburense transformed NCB (160 mg/l) to ClA (60 mg/l) in 10 hours (Fig. 5).

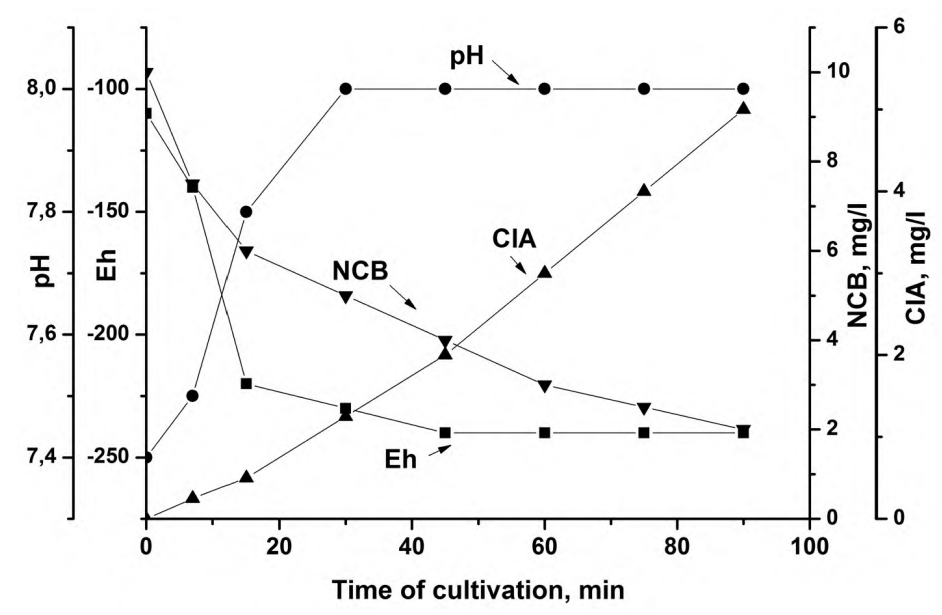

Fig. 4. Transformation of NCB by growing E.coli culture

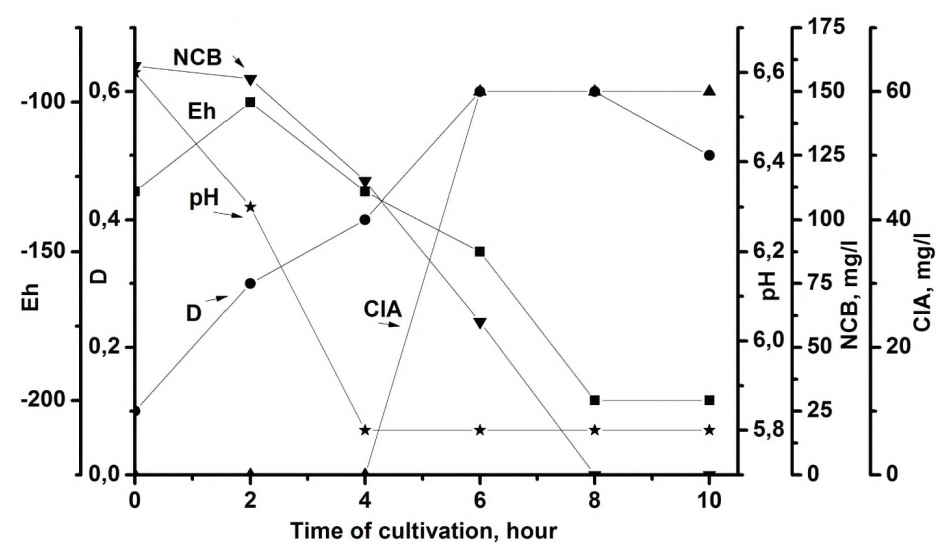

Fig. 5. Transformation of NCB by Clostridium lituseburense

In both cases, $\mathrm{NCB}$ reduced in $\mathrm{ClA}$ independently of the xenobiotic concentration in the medium. The reaction rate increased with a decreasing of redox potential of the medium.

Thus, Ecuador mountain jungle soil microbial community and museum cultures interacted with NCB. However, there were some significant differences. First of all, the museum cultures E.coli and C.lituseburense transformed $\mathrm{NCB}$ in ClA, while Ecuador microbial community provided complete degradation of NCB. This was evidenced by the absence of $\mathrm{ClA}$ accumulation in the culture fluid. In addition, in the case of museum cultures decreasing of NCB concentration correlates with decreasing of redox potential. In the experiment with Ecuador microbial community this was not observed. Decreasing of NCB concentration started on the 5th day of cultivation, whereas biomass growth and the change in $\mathrm{pH}$ and Eh started on 
the 1-2nd day already. So, obviously, during this time Ecuador microbial community adapted to $\mathrm{NCB}$, and only then started interactions that led to the xenobiotic destruction.

Thus, microbial communities of ecosystems with constant physicochemical conditions (cave clays) and Ecuador tropical ecosystems (mountain and rainforest jungle soils) were highly resistant to NCB. They show similar homeostasis parameters in the presence of xenobiotic: the first and the second types of responses on NCB influence, the maximum permissible concentration ranged between $200-300 \mathrm{mg} / \mathrm{l}$. NCB had a pronounced toxic effect on the studied microbial communities. While the $\mathrm{NCB}$ concentration increases, $\mathrm{CFU}$, colony number morphotypes and their diameter decreased. The studied microbial communities proceeded complete xenobiotic degradation after adaptation to it.

Таширев О.Б., Суслова О.С., Рокитко П.В.

Інститут мікробіології та вірусології ім. Д.К. Заболотного НАН України, Киїь

\section{КІЛЬКІСНІ ПОКАЗНИКИ ГОМЕОСТАЗУ МПКРОБНИХ УГРУПОВАНЬ ІРУНТІВ ЕКВАДОРУ ТА ГЛИН КАРСТОВИХ ПОРОЖНИН ЗА ВПЛИВУ П-НІТРОХЛОРБЕНЗОЛУ}

Резюме

Показано кількісні показники мікробних угруповань глин карстових порожнин Західної України та Абхазії (Мушкарова Яма та Куйбишевська) та грунтів тропічпих екосистем Еквадору до дії $n$-нітрохлорбензолу (НХБ). Для зазначених мікробних угруповань встановлено максимально допустимі конщентрації та типи відповідей на дію ксенобіотика. Відповідь першого типу характерна для мікробних угруповань глин Мушкарової Ями та тропічного лісу Еквадору. Відповідь другого типу - для мікробних угруповань глин карстової порожнини Куйбишевська та гірських джунглів Еквадору. Максимально допустимі концентрапії НХБ для Мушкарової Ями складають 200 мг/л, для інших досліджуваних мікробних угруповань 300 мг/л. Встановлено, що мікробні угруповання не тільки високостійкі до НХБ, але і взасмодіють із ним, руйнуючи ксенобіотик і знижуючи його концентрацію в 4 рази.

Ключові слова: $n$-нітрохлорбензол, карстові порожнини, тропічні екосистеми Еквадору, мікробні угруповання.

Таиирев А.Б., Суслова О.С., Рокитко П.В.

Институт микробиологии и вирусологии им. Д.К. Заболотного НАН Украины, Киев

\section{КОЛИЧЕСТВЕННЫЕ ПОКАЗАТЕЛИ ГОМЕОСТАЗА МИКРОБНЫХ СООБЩЕСТВ ПОЧВ ЭКВАДОРА И ГЛИН КАРСТОВЫХ ПОЛОСТЕЙ ПРИ ВЛИЯНИИ П-НИТРОХЛОРБЕНЗОЛА}

\section{Резюме}

Показаны количественные показатели устойчивости микробных сообществ Западной Украины и Абхазии (Мушкарова Яма и Куйбышевская) и почв тропических екосистем Эквадора к действию $n$-нитрохлорбензола (НХБ). Для указанных микробньх сообществ установлены максимально допустимые конщентрации НХБ и типы ответов на действие ксенобиотика. Ответ первого типа характерен дпя микробных сообществ глин Мушкаровой Ямы и тропического леса Эквадора. Ответ второго типа - дпя микробных сообществ глин карстовой полости Куйбьшевская и горншх джунлей Эквадора. Максимально допустимые кощцентрации НХБ для Мушкаровой Ямы составляют 200 мг/л, для других исследуемых микробных сообществ - 300 мг/л. Установлено, что микробные сообщества не только высокоустойчивы к НХБ, но и взаимодействуют с ним разрушая ксенобиотик и снижая его конщентрацию в 4 раза.

Ключевые слова: $n$-нитрохлорбензол, карстовые полости, тропические экосистемы Эквадора, микробные сообщества. 
1. Gvozdyak P.I., Mogilevich N.F.,Tashyrev A.B. Transformation of p-nitrohlorobenzene by E.coli // Microbiologiya. - 1983. - Vol. 52. - № 1. - P. 22-25.

2. Tashyrev A.B., Matveeva N.A., Romanovskaya V.A., Tashyreva A.A. Rokitko P.V. Polyresistance superstability and heavy metals Antarctic microorganisms // Dopovidi Nacional'noï Akademï Nauk Ukraïni. - 2007. - № 11. - P. 170-175.

3. Tashyrev A.B., Rokitko P.V., Levishko A.S., Romanovskaya V.A., Tashyreva A.A. Resistance to toxic metals of chemoorganotrophic bacteria isolated from the Antarctic cliffs // Mikrobiol. zhurnal. - 2012. - 74, № 2. - P. 3-7.

4. Tashyrev A.B., Romanovskaya V.A., Rokitko P.V., Tashyreva A.A. Multiple resistance to toxic metals of Antarctic cliffs microorganisms (o.Galindez) // Ukr. antarktichny zhurnal. - 20112012. - № 11-12. - P. 212-221.

5. Tashyrev A.B., Tihnenko S.A. Transformation of $p$-ntrohlorbenzene by obligate anaerobic microorganisms. - In the book. "Microbiology of water treatment": Abstracts 2 Union Conference. Kiev, 1982, p.194.

6. Li Haixiang, Yang Xin, Zhong Fohua, Li Junying, Xia Siqing. Experimental study on para-nitrochlorobenzene (p-NCB) removal from groundwater by autohydrogenotrophic microorganism// Chinese Journal of Environmental Engineering. - 2011 - № 2. - P. 43-48.

Отримано 10.06.2014 